\title{
Allelopathic effect of Passiflora alata Curtis extracts on seed germination
}

\author{
Allan Rocha de Freitas, José Carlos Lopes, Liana Hilda Golin Mengarda, \\ Rafael Fonsêca Zanotti, Luan Peroni Venancio
}

Universidade Federal do Espírito Santo, Alegre, ES, Brazil

${ }^{*}$ Corresponding author, e-mail: allanrochaf@gmail.com

\begin{abstract}
Many plant chemical compounds can interfere on seed germination and on the development of other plants. Thus, this research aimed to verify the effect of sweet passion fruit seeds (Passiflora alata Curtis) extracts, under lettuce seed germination and lettuce seedlings growing. The experiment was carried out in a controlled environment. The treatments were: T1-distilled water as a control; T2-embryo extract; T3- tegument extract; T4- whole grain extract; T5- soaking solution. Lettuce seed (Lactuca sativa L.) cv. Babá de Verão, was used as a bioindicator of the allelopathic effect. When the treatment of embryo extract of sweet passion fruit was applied, a lower germination percentage and lower speed emergence rate of lettuce seeds were observed. The largest number of abnormal seedlings was observed from seeds germinated in the embryo extract (T2) and the soaking solution (T5). The sweet passion fruit embryo extract discloses compounds that are able to inhibit the germination and can negatively influence the development of lettuce seedlings.
\end{abstract}

Keywords: initial growth, inhibition, sweet passion fruit

\section{Efeito alelopático de Passiflora alata Curtis na germinação de sementes}

\section{Resumo}

Muitas substâncias químicas presentes nos vegetais podem apresentar capacidade de interferir na germinação de sementes e no desenvolvimento de outras plantas. Assim, objetivou-se com esta pesquisa verificar o efeito de extratos de sementes de maracujá doce (Passiflora alata Curtis), sob a germinação de sementes e crescimento de plântulas de alface. O experimento foi conduzido em ambiente controlado. Os tratamentos consistiram em: T1: água destilada como testemunha; T2: extrato de embrião; T3: extrato do tegumento; T4: extrato das sementes inteiras; T5: solução de embebição. Utilizou-se como bioindicadores do efeito alelopático dos extratos sementes de alface (Lactuca sativa L.) cv. Babá de Verão. O extrato do embrião das sementes maracujá doce reduziu a porcentagem de germinação e o índice de velocidade de germinação das sementes de alface. O maior número de plântulas anormais foi observado a partir de sementes germinadas no extrato do embrião (T2) e na solução de embebição (T5). O extrato do embrião das sementes de maracujá doce apresenta compostos capazes de inibir a germinação e influenciar negativamente o crescimento inicial das plântulas de alface.

Palavras-chave: crescimento inicial, inibição, maracujá doce 


\section{Introduction}

Brazil stands out for being one of the largest producers of passion fruit on the world. The sweet passion fruit (Passiflora alata) is an herbaceous and usually clambering plant with subcoriaceous leaves, isolated axillary and fragrant flowers, fruit with juicy flesh, with sweet and pleasant taste (Alexander et al., 2009). It is commercially grown mainly for the production of fruits for fresh consumption, reaching high prices both in the domestic and external markets (Santos et al, 2011; Nicolini et al, 2012.).

Traditionally, the commercial orchards in Brazil are established for seedlings obtained from seeds, being common the low germination percentage, which can be associated to dormancy mechanisms. The main factors that determine the dormancy phenomenon are the tegument impermeability, physiological immaturity, immature embryo and the presence of inhibitory substances (Bewley \& Black, 1982).

Many chemical compounds present in plants can be able to interfere on their own germination, as well as in other species germination. To identify the presence of these compounds, bioassays with other plant species are recommended. The lettuce (Lactuca sativa L.) is considered a model plant for these studies because of its high sensitivity, even at low allelochemicals concentrations (Borges et al, 2011; Nicolini et al, 2012; Reichel et al, 2013.).

Thus, the aim of this research was to determine the effect of sweet passion fruit seed extracts on lettuce seed germination and seedlings growth.

\section{Materials and Methods}

For the experiment, sweet passion fruit seeds (Passiflora alata) from fruits collected in orchards of Alegre-ES, Brazil were used. The seeds were manually extracted from fruits, passed in wire sieves to help on aryl extraction and dried on filter paper. Two batches of 100 seeds were used, being immersed in $75 \mathrm{ml}$ of distilled water and kept in BODs at a constant temperature of $25^{\circ} \mathrm{C}$ for 24 hours.

The experiment was carried out in a completely randomized design with four replications of 25 seeds each. The treatments were: $\mathrm{T1}$ : distilled water as a control; T2: embryo extract $(0.387 \mathrm{~g})$; T3: tegument extract $(0.387$ g); T4: whole seed extract (0.387 g); T5: soaking solution, using the solution that in which the 100 seeds were immersed in distilled water for 24 hours. The different extracts of fresh passion fruit seeds were obtained by maceration using a crucible and adding $5 \mathrm{~mL}$ of distilled water. After maceration it was filtered using a $1 \mathrm{~mm}$ sieve, obtaining the extracts.

Lettuce seeds (Lactuca sativa L.) cv. Baba de Verão were used as bioindicators and were placed in Petri dishes with a germitest ${ }^{\circledR}$ paper.

These were distributed on Petri dishes coated with a germitest ${ }^{\circledR}$ paper. The total of $1.67 \mathrm{~mL}$ of each treatment ( $\mathrm{T} 1$ to $\mathrm{T} 5$ ), that corresponded to 2.5 times the dry paper weight, was added to petri dishes, for each repetition. Plates were sealed with semi-transparent flexible film and placed at temperatures from $20-30^{\circ} \mathrm{C}$ in a photoperiod of 8-16 light/dark hours in BODs.

The evaluation of the number of germinated seeds was performed daily until the germination stabilization, which occurred nine days after the installation of the experiment. At the end, the germination percentage (Brazil, 2009), germination speed index (Maguire, 1962), shoot and root length, seedlings fresh and dry weight and abnormal seedlings rating were evaluated.

Analysis of the electric conductivity ( $\mu S$ $\mathrm{c}^{-1} \mathrm{~g}^{-1}$ ) and the $\mathrm{pH}$ in four sub-samples with 20 $\mathrm{ml}$ of the solutions ( $\mathrm{T} 1$ to $\mathrm{T} 5$ ) using conductivity meter (31 DM Digimed) were carried out. The nutrient content of the extracts was determined and the analysis of Fe and $\mathrm{Mn}$ were performed by atomic absorption spectrophotometry, according to AOAC (1997). The P, K, Mg and Zn were determined from the digestion with atomic absorption spectrometry flame (Embrapa, 2009).

The results were submitted to analysis of variance and the means were compared by Tukey's test at $5 \%$ of probability.

\section{Results and Discussion}

The use of embryo extract (T2) of sweet passion fruit seeds reduced the germination percentage and the germination speed 
index of lettuce seeds, indicating allelopathic interference of compounds of sweet passion fruit seeds on lettuce germination (Table 1).

Table 1. Germination (GER), speed emergency index (SEI), root lenght (RL), shoot lenght (SL), fresh mass (FM), dry mass (DM) e abnormal seedlings (AS) of lettuce seeds treated with Passiflora alata Curtis extracts.

\begin{tabular}{cccccccc}
\hline TRAT** & GER & SEI & RL & SL & FM & DM & AS \\
\hline T1 & $91.00 \mathrm{a}^{*}$ & $9.92 \mathrm{a}$ & $28.30 \mathrm{~b}$ & $29.21 \mathrm{a}$ & $27.40 \mathrm{a}$ & $0.88 \mathrm{a}$ & $5.00 \mathrm{~b}$ \\
T2 & $39.00 \mathrm{~b}$ & $2.60 \mathrm{~b}$ & $6.54 \mathrm{c}$ & $9.29 \mathrm{c}$ & $13.30 \mathrm{e}$ & $0.52 \mathrm{c}$ & $21.30 \mathrm{a}$ \\
T3 & $81.00 \mathrm{a}$ & $9.15 \mathrm{a}$ & $38.97 \mathrm{a}$ & $15.64 \mathrm{~b}$ & $19.82 \mathrm{~cd}$ & $0.73 \mathrm{~b}$ & $0.00 \mathrm{~b}$ \\
T4 & $85.00 \mathrm{a}$ & $8.99 \mathrm{a}$ & $38.63 \mathrm{a}$ & $15.05 \mathrm{bc}$ & $16.61 \mathrm{de}$ & $0.70 \mathrm{~b}$ & $5.00 \mathrm{~b}$ \\
$\mathrm{~T} 5$ & $80.00 \mathrm{a}$ & $8.91 \mathrm{a}$ & $40.73 \mathrm{a}$ & $19.71 \mathrm{~b}$ & $23.77 \mathrm{ab}$ & $0.75 \mathrm{ab}$ & $9.00 \mathrm{ab}$ \\
\hline $\mathrm{CV}(\%)$ & 6.69 & 8.42 & 15.08 & 9.76 & 8.44 & 9.14 & 17.51 \\
\hline $\mathrm{F}_{\text {cal }}$ & 49.71 & 46.45 & 22.07 & 14.35 & 23.42 & 7.55 & 7.13 \\
\hline "Means & &
\end{tabular}

Agreeing with the results, negative effects on germination and vigor of lettuce seeds were observed by some authors in experiments with plant extracts. The use of Eugenia uniflora L. seed extracts decreased the percentage of germination of lettuce seeds, indicating allelopathic interference of chemical compounds (Delgado \& Barbedo, 2011). The phenolic compounds in the edible part of papaya seed husk promoted an inhibition of germination, reduced the germination speed index and the primary root growth of lettuce (Tokuhisa et al., 2007). Aqueous extracts of Piper mikanianum leaves have allelopathic compounds that can exerted action on radish seeds and seedlings, reducing the germination and the initial growth (Borella et al., 2012). Numerous chemical compounds such as phenolic acids, coumarins, terpenoids, flavonoids, alkaloids, tannin and quinones, are found in plants chemical composition that can lead to harmful or beneficial effects on other plants and organisms (Souza et al., 2005).

Regarding to lettuce seedlings initial growth under sweet passion fruit extracts influence, a reduction on root and shoot length and seedling fresh and dry mass were observed
(Table 1). The high number of abnormal seedlings was observed when the treatments with embryo extracts (T2) and the soaking solution (T5) were used.

The results that can be verified on Table 1 are in accordance with the results of Nicolini et al. (2012) and Voltarelli et al. (2012) that observed that sour passion fruit extracts caused a reduction in the length and fresh weight of lettuce roots and lower growth of lettuce seedlings under the influence of Gleichenella pectinata seed extracts (Willd), respectivelly.

Through the electrical conductivity test (Table 2) the concentration of solutes and compounds present in extracts solutions were evaluated. High values for treatment T2 was observed, which was also the treatment in which lettuce seeds had lower germination and post seminal development. This method consists in measuring electrolytes leached by seed in the imbibition water (Souza et al., 2009), thus, the negative effect of the extracts may be attributed to the leaching of solutes present in Passiflora alata, capable of inhibiting germination. There was no difference between the solutions $\mathrm{pH}$ (Table 2).

Table 2. Chemical analysis, electric condutivity (EC) and $\mathrm{pH}$ of the solutions from Passiflora alata Curtis extracts.

\begin{tabular}{|c|c|c|c|c|c|c|c|}
\hline TRAT** & $\mathrm{P}(\mathrm{mg} / \mathrm{L})$ & $\mathrm{K}(\mathrm{mg} / \mathrm{L})$ & $\mathrm{Fe}(\mathrm{mg} / \mathrm{L})$ & $M g(m g / L)$ & $\mathrm{Zn}(\mathrm{mg} / \mathrm{L})$ & $\mathrm{EC}\left(\mu \mathrm{S} \mathrm{cm}^{-1} \mathrm{~g}^{-1}\right)$ & $\mathrm{pH}$ \\
\hline $\mathrm{Tl}$ & $34.77 e^{*}$ & $0.10 \mathrm{~d}$ & $0.01 \mathrm{c}$ & $0.02 \mathrm{~d}$ & $0.01 \mathrm{~d}$ & $1.27 \mathrm{e}$ & $7.04 \mathrm{a}$ \\
\hline T2 & $372.64 a$ & $1.62 \mathrm{~b}$ & $0.28 a$ & $0.26 a$ & $0.17 a$ & $847.91 \mathrm{a}$ & $7.12 a$ \\
\hline T3 & $102.26 \mathrm{~d}$ & $0.55 \mathrm{c}$ & $0.23 a$ & $0.10 \mathrm{c}$ & $0.06 \mathrm{c}$ & $71.83 \mathrm{~d}$ & $7.31 \mathrm{a}$ \\
\hline T4 & $298.60 \mathrm{~b}$ & $0.36 c$ & $0.27 a$ & $0.12 c$ & $0.03 d$ & $126.57 \mathrm{C}$ & $7.06 a$ \\
\hline T5 & $239.68 \mathrm{c}$ & $2.11 \mathrm{a}$ & $0.06 \mathrm{~b}$ & $0.21 \mathrm{~b}$ & $0.10 \mathrm{~b}$ & $596.25 \mathrm{~b}$ & $6.75 a$ \\
\hline CV (\%) & 2.67 & 6.57 & 9.44 & 1.39 & 1.293 & 25.72 & 22.01 \\
\hline $\mathrm{F}_{\mathrm{cal}}$ & 859.58 & 364.73 & 80.28 & 3386.80 & 71325.23 & 54.65 & 31.65 \\
\hline
\end{tabular}


It was observed through extracts chemical analysis (Table 2) higher concentrations of $\mathrm{P}, \mathrm{K}, \mathrm{Mg}$ and $\mathrm{Zn}$ on treatment 2, when compared to others, except for treatment 5 when $\mathrm{K}$ was evaluated, and the lack or excess of nutrients can interfere in plant development. For $\mathrm{pH}$, there was no difference among the evaluated treatments.

\section{Conclusions}

The embryo extract (T2) of Pasiflora

alata Curtis seeds contains compounds that can negatively influence the lettuce seedling development.

\section{Acknowledgments}

To CNPq for the research productivity scholarships for the second and third authors.

\section{References}

Alexandre, R.S.; Bruckner, C.H.; Lopes, J.C. 2009. Seleção de matrizes e comportamento do maracujazeiro quanto aos métodos de propagação. In: Alexandre, R.S.; Bruckner, C.H.; Lopes, J.C. Propagação do maracujazeiro: aspectos morfológicos, fisiológicos e genéticos. EDUFES, Alegre, Brasil. p 15-24.

Association of Official Agricultural ChemistsAOAC. 1997. Official Methods of Analysis of the Association of Official Agriculture Chemists. AOAC International, Gaithersburg, USA. $1141 \mathrm{p}$

Bewley, J.D., Black, M. 1982. Phisiology and biochemistry of seeds in relation to germination: viability, dormancy and environmental control. SPRINGER-VERLAG, Berlin, Germany. 375 p.

Borges, C.S., Cuchiara, C.C., Silva, S.D.A., Bobrowski, V.L. 2011. Efeitos citotóxicos e alelopáticos de extratos aquosos de Ricinus communis utilizando diferentes bioindicadores. Tecnologia \& Ciência Agropecuária 5: 15-20.

Borella, J., Martinazzo, E.G., Aumonde, T.Z., Amarante, L., Moraes, D.M., Villela, F.A. 2012. Respostas na germinação e no crescimento inicial de rabanete sob ação de extrato aquoso de Piper mikanianum (Kunth) Steudel. Acta Botanica Brasilica 26: 415-420.

Brasil. 2009. Regras para análise de sementes. MAPA-ACS, Brasília, Brasil. 395p.

Delgado, L.F., Barbedo, C.J. Atividade inibidora da germinação em extratos de sementes Eugenia uniflora L. 2011 . Revista Brasileira de sementes 33: 463-471.
Empresa Brasileira de Pesquisa Agropecuária EMBRAPA. 2009. Manual de análises químicas de solos, plantas e fertilizantes. Informação Tecnológica, Brasília, Brasil. 628p.

Maguire, J. D. 1962. Speed of germination: aid in selection an evaluation for seedling emergence and vigor. Crop Science 2: 176-177.

Nicolini, J. T., Bido, G. S., Zonetti, P. C. 2012. Efeito do extrato aquoso de Passiflora edulis Sims sobre a germinação e crescimento inicial de alface. Revista em Agronegócios e Meio Ambiente 5: 191-203.

Reichel, T., Barazetti, J.F., Stefanello, S., Paulert, R., Zonetti, P.C. 2013. Allelopathy of leaf extracts of jatropha (Jatropha curcas L.) in the initial development of wheat (Triticum aestivum L.). Idesia 30:45-52.

Santos, V.A., Ramos, J.D., Oliveira, M.C., Silva, E.A. 2011. Tipos de enxertia em diferentes idades de plantas de maracujazeiro. Revista Brasileira de Fruticultura 33: 1359-1363.

Souza, L.A., Carvalho, M.L.M., Kataoka, V.Y., Oliveira, J.A. 2009. Teste de condutividade elétrica para avaliação da qualidade fidiológica de sementes de mamona. Revista Brasileira de Sementes 31: 60-67

Souza, S.A.M., Stein, V.C., Cattelan, L.V., Bobrowski, V.L., Rocha, B.H.G. 2005. Utilização de sementes de alface de rúcula como ensaios biológicos para avaliação do efeito citotóxico e alelopático de extratos aquosos de plantas medicinais. Revista de Biologia e Ciências da Terra 5: 3-9.

Tokuhisa, D., Dias, D.C.F.S, Alvarenga, E.M., Hilst, P.C., Demuner, A.J. 2007. Compostos fenólicos inibidores da germinação em sementes de mamão (Carica papaya L.). Revista Brasileira de Sementes 29: 180-188.

Voltarelli, V.M., Ribeiro, J.P.N., Lima, M.I.S. 2012. Allelopathic potential of Gleichenella pectinata (Willd.) Acta Botanica Brasilica 26: 779-784. 